\title{
Exploring the challenges in implementing supplier environmental performance measurement models: A case study
}

\author{
Andrea Genovese, S.C. Lenny Koh, Niraj Kumar*, Pradhumn Kumar Tripathi \\ Logistics and Supply Chain Management Research Centre \\ Sheffield University Management School \\ Conduit Road, Sheffield S10 1FL. \\ *Corresponding author \\ email-N.Kumar@sheffield.ac.uk
}

\begin{abstract}
This study aims to explore the challenges associated with implementing supplier environmental performance measurement models in context of a global supply chain. After a thorough literature review on the topic, a case study based research methodology is adopted to investigate the real-life perspective of the issues encountered while evaluating the supplier performance in a sustainable supply chain. An in-depth study of one of the biggest Fast Moving Consumer Goods (FMCG) companies in UK is discussed and analysed in this paper. Findings of this research will pave the way for developing a robust, efficient and usable environmental performance measurement framework in a supply chain.
\end{abstract}

Keywords: Green Supply Chain, Performance measurement, Supplier evaluation, Case study. 


\section{Introduction}

In a competitive market, consumers demand cheaper and higher quality products, on-time delivery and excellent after-sale services. Therefore, companies need to cut costs while maintaining a high level of quality and after-sale services. Various studies devoted to the analysis of customer-supplier relationships highlighted that attention should be paid on the management of the entire supply chain in order to improve the quality of services and products provided to the final consumers. Moreover, with the trend to outsource a constantly increasing quota of the value-chain activities, purchasing decisions become crucial (Harland, 1996; Gunasekaran and Irani, 2010). Thus, supplier evaluation process plays a key role in designing an efficient supply chain (Saen, 2007). In particular, suppliers' evaluation and selection has assumed a strategic role in determining large customer firms' competitiveness. Consequently, customers devote more and more resources to both suppliers' development programs (Lamming et al., 1996) and early suppliers' involvement (O'Neal, 2006). Thus, supplier selection has received extensive attention in the literature (de Boer et al., 2001; de Boer and van der Wegen, 2003).

At the same time, in recent years, an increasing environmental awareness has favoured the incorporation of green and sustainability thinking in Supply Chain paradigms (Seuring and Müller, 2008). Thus, green criteria have started to be considered also in the supplier performance evaluation literature (Sarkis, 2003). However, at present, most of the work on these topics has been aimed at identifying criteria, methods and models to solve the problem from a mathematical and theoretical point of view, with relatively little emphasis on researches that highlight and understand the challenges faced by organizations with the implementation of such models and methods.

As a response to these academic gaps, this paper focuses on issues and challenges of implementing supplier environmental evaluation practices in the corporate world. In 
particular, the paper presents a case study regarding the implementation process of an environmental scorecard for green supplier evaluation in a large multinational organisation operating in the Fast-Moving Consumer Goods industry, in order to understand the real-life challenges related to it. An action-research based methodology is adopted to investigate the development of a framework to measure supply chain performance.

The paper is divided in four main sections. First, the extant literature about supplier evaluation and selection with an emphasis on green and sustainability aspects, is reviewed. Gaps emerging from the literature are analysed, with emphasis on the lack of practical work and links to strategic implications. Then, details of the utilised methodology are presented. Furthermore, findings from the case study are illustrated, linking them to the literature review. The final section presents a detailed discussion followed by some concluding comments and managerial implications.

\section{Literature Review}

This section is structured in the following way. Firstly, generalities about the supplier evaluation problem and relevant literature are discussed. Thereafter, the impact of green and sustainability issues in this field of study is illustrated. Finally, gaps in the extant literature are highlighted.

\section{The Supplier Evaluation Problem: Generalities}

The Supplier Evaluation Problem consists of the definition of models and methods to analyze and measure the performance of a set of suppliers (vendors) on a set of dimensions (criteria) in order to improve customer competitiveness. Several papers (Dickson, 1966; Bhutta, 2003) analysed the various methods used by buyers for supplier evaluation, finding that the Supplier Evaluation Problem is an intrinsically multi-attribute problem, since many qualitative and 
quantitative factors, very often conflicting with each other, should be taken into account (Dickson, 1966; Bhutta and Huk, 2002; Bhutta, 2003; Sonmez, 2006; Ramanathan, 2007). This implies that, while selecting the best supplier, firms need to consider some tradeoffs among conflicting criteria. However, still most of the buyers consider cost as a major criteria for supplier selection. Moreover, it is possible to notice that selected criteria and weights assigned to each criterion strongly vary across industries (Lee \& Billington, 1992; Bhutta, 2003).

In the academic literature, several decision making techniques have been developed in order to support the supplier evaluation process; the most of them are deriving from the application of mathematical methods, including applications of the following methodologies (Ho et al., 2010):

- Data Envelopment Analysis (Liu et al., 2000; Forker and Mendez, 2001);

- Mathematical Programming (Hong et al., 2005; Ng, 2008);

- Analytic Hierarchy Process (Saaty, 1980) and Analytic Network Process (Saaty, 2001) (for a complete review, see Bruno et al., 2012);

- Case-Based Reasoning (Choy and Lee, 2002);

- Fuzzy Set Theory (Florez-Lopez, 2007; for a complete review, see Bhutta, 2003);

- Other multi-attribute decision making methods (Huang and Keska, 2007).

However, despite the growing number of applications, there is still an open issue about the practical usability of these approaches, as they cannot easily accommodate qualitative factors which play an important role in supplier selection especially when firm is willing to develop supplier partnerships (De Boer et al., 2001; Huang and Keska, 2007). Indeed, there are few challenges associated with available models. First of all, decision makers are often required to undertake training to utilise the model; moreover, a single model is not sufficient for all 
purchasing situations, as criteria and their importance can strongly depend on the product to be sourced. Furthermore, de Boer and van der Wegen (2003) and Bruno et al. (2012) found that the lack of widely accepted cross-industry performance measurement systems makes more difficult to measure the performance of entire supply chains and their members (as already pointed out by Lee and Billington (1992)). Therefore, it is important that the performance measurement criteria should be designed in such a way that they can be easily understandable by all supply chain members and offer less opportunity for manipulation (Gunasekaran et al., 2004; Bruno et al., 2012).

\section{Environment, Sustainability and Supply Chain Management}

Recent changes in the global environment have also affected consumers' behaviour. Nowadays consumers are starting to become more conscious about the product they buy, preferring environment friendly, recyclable and energy efficient ones (do Paço and Raposo, 2009). These changes in the consumer perception, coupled to increasing legislative pressures, are forcing firms to look towards greener production, encompassing the whole supply chain. Consequently, academic and corporate interest in sustainable and green supply chain management has risen considerably in recent years (Vachon and Klassen, 2006 and 2008). This can be seen looking at the consistent increase in papers published on this topic in international journals (Seuring et al., 2008). Hervani et al. (2005) define Green Supply Chain Management as the "addition of the Green component to supply chain management, addressing the influence and relationships of supply chain management to the natural environment. Motivated by an environmentally-conscious mindset, it can also stem from a competitiveness motive within organisation”.

Seuring et al. (2008) work introduces a more complete definition, that describes "sustainable supply chain management as the management of material, information and capital flows as 
well as cooperation among companies along the supply chain while taking goals from all three dimensions of sustainable development, i.e., economic, environmental and social, into account which are derived from customer and stakeholder requirements".

This rising interest has also influenced the supplier evaluation literature. Indeed, The emergence of these paradigms that have hybridized the Supply Chain Management theories with environmental, social and sustainability concepts is starting to influence also the way in which partners and suppliers are selected and evaluated within a supply chain (Dekker, 2003; P\&G, 2010). In his seminal work, Noci (1997) identified four types of indicators as "Green" competencies, Current environmental efficiency, Net life cycle cost, and Supplier's "Green" image, which will help to design the performance evaluation system for suppliers. Most of the papers utilise mathematical multi-criteria decision making methodologies to cope with the problem, in order to provide suppliers ranking taking into account environmental criteria: Handfield et al. (2002), Sarkis (2003), Lu et al. (2007), Kannan et al. (2008), Hsu and Hu (2009), Zhu et al. (2010) develop methodologies based on the Analytic Hierarchy Process and its network variant Analytic Network Process (AHP/ANP) (Saaty, 1980, 1994, 2001); Bai and Sarkis (2010a and 2010b) utilise the Rough Set Theory and Huang and Keska (2007) develop a model based on Multi-Attribute Utility Theory; Fuzzy Logic is employed by Humphreys et al. (2006), Chan and Kumar (2007), Jain et al. (2007) and Chan et al. (2008); Sasikumar and Noorul Haq (2010) implement a methodology based on the combination of Linear Programming and Fuzzy Multi-Criteria Decision Making techniques, while Tsai and Hung (2009) combine Fuzzy Logic and Goal Programming; Awasthi et al. (2010) combine Fuzzy Logic and TOPSIS methodology.

Gaps Emerging from the Literature Review 
The above literature review shows that there is a growing interest towards supplier environmental evaluation. However, in the real-world practice, firms are facing difficulties to incorporate environmental and sustainability criteria in their supplier evaluation practice. As highlighted by Genovese et al. (2013), in the corporate practice the interest in green issues in the supplier selection procedures is still quite limited. Firms (both SMEs and larger organizations) tend to manage their supplier selection processes still in a very traditional way, by utilizing standard measures (mainly related to cost, quality, delivery punctuality). This is mainly due to the fact that it is not easy to make suppliers an integral part of firm's sustainability programme; moreover, environmental criteria (such as, for instance, Carbon Emissions) are not easily measurable. As highlighted by Genovese et al. (2013), the only enviromental criteria that firms are somewhat starting to incorporate are related to waste management. This can be interpreted as a result of the approval of more restrictive environmental regulations (for example, RoHS and RAEE in the European Union) aimed at making manufacturers, wholesalers and final distributors fully responsible of the environmental impact of their products.

Therefore, while the number of literature applications is growing, there is little empirical evidence of the practical usefulness of such tools. This aspect has been already highlighted, in the broader case of the generic Supplier Selection problem, by several studies (Weber et al., 1991; de Boer and van der Wegen, 2003; Bruno et al., 2012; Genovese et al., 2013). Also in the case of the supplier environmental evaluation problem, very often, the proposed models are tested on generic applications, numerical examples and computational experiments, with less emphasis on the problems emerging in the practical implementation of the methodology, on its strengths and weaknesses, and on the appreciation given them by the practitioners and managers (Genovese et al., 2013). 
Furthermore, even if a test of the developed methodology in a real corporate environment is performed, results are not always encouraging in terms of usability. As pointed out by Huang and Keska (2007), researchers overly emphasized the need of quantitative methods and overlooked the importance of integration with business strategic thinking when it comes to supplier evaluation. Indeed, many firms failed to reap maximum benefit from their supply chain because they were unable to develop effective performance measure and metrics. Despite the fact that financial and non-financial measures are crucial for performance measurement, most firms were unable to represent them in a balanced framework. Gunasekaran et al. (2004) found that often firms are using multiple metrics to measure the various activities (plan, source, make/assemble, and delivery etc.) of supply chain for performance evaluation, which makes performance evaluation process more difficult and complicated (see also Lyons et al., 2005).

In addition, at the moment, there is no global standard available (both in the literature and in the market) which could be used as a benchmark to monitor the environmental performance for each and every firm in any industry. The main reason behind this is that firms and industry vary in size and capability, thus their responses and approaches towards the environmental performance also vary. The same difficulty is currently being faced within leading global companies that are trying to develop such a global standard for their own supply chains (2degrees, 2011).

Given these gaps in the extant literature, this paper tries to investigate the challenges in the implementation of green supply chain models for supplier performance measurement mechanisms in the practice. Paper focuses on issues and challenges of implementing green supplier evaluation models in real-life. Several key barriers to the transfer of theoretical models into practice are identified, including the intrinsic difficulty in designing evaluation 
tools that can fit to diverse industries and in finding benchmarks for comparing suppliers' performances.

\section{Research Methodology}

In this research, a case study based research methodology is adopted to understand the challenges involved in the implementation process of an environmental supply chain performance evaluation model. In-depth case study is recognised in the literature as the most appropriate method to explore unknown phenomena. Eisenhardt (1989) describes case study research as the strategy which focuses on understanding the dynamics present within single settings. Yin (2003) suggests that case studies are appropriate for the study of contemporary events where it is not necessary to control behavioural events or variables. Single case study is appropriate if the objective of the research is to explore the previously unexplored subject, whereas multiple case studies are desirable when the intention of the research is descriptive, theory building or theory testing (Yin 2003). The key strengths of the case study

methodology are identified as follows (Benbasat et al. 1987): (i) It provides opportunity to study the phenomenon in its natural setting, and understanding and observing the actual practice help to generate meaningful and relevant theory, (ii) it allows the much more meaningful question of why, rather than just what and how, (iii) it helps to perform early exploratory investigations where variables are still unknown.

In this research, an in-depth case study of one of biggest FMCG Companies in United Kingdom is conducted. The identity of the company is concealed here to protect its business interests. The company will be called as 'Alpha' in rest of the paper. The qualitative study of 'Alpha' helps to understand the challenges of implementing suppliers environmental performance evaluation system in the real-life perspective. Alpha is a truly global company and offers a range of products across the world. Understanding the current business 
environment with more emphasis on the green supply chain, Alpha aims to double its sales by 2020 in a sustainable way. Therefore, Alpha plans to improve the quality of its products along with the reduction of greenhouse gases (GHGs), water usage and waste production. Alpha plans to achieve the United Nation's requirement of reducing GHGs by $50-85 \%$ till 2050 . In 2010, over 100 manufacturing sites across the world were certified to ISO 14001. However, the company has understood that, in order to achieve its ambitious targets, suppliers must be engaged. Alpha needs to select, evaluate and monitor the suppliers on the basis of a set of environmental criteria. Therefore, an environmental performance evaluation system is developed to measure, monitor and evaluate the environmental performance of the key suppliers of Alpha. The paper attempts to understand the environmental performance measurement model used by Alpha for a specific supply chain related to a given product division (the one of deodorant products) and explores the issues being encountered in its successful implementation in supply chain.

A semi-structured interview based technique is used to collect data from Alpha. A number of one-to-one interviews are conducted with managers at the 'Alpha' site to identify and understand the supplier environmental evaluation process the company wants to implement. Semi-structured interviews involve focussed open-ended questions to enable the interviewees to expand on what they consider to be important (Meredith et al. 1989, Barnes 2001). Semistructured interviews allow the interviewer to probe more deeply to uncover previously hidden details and open up new streams of enquiry (Burgess 1982; Berg 2004). Interviewees were asked to describe their awareness about Green Supply Chain (GSC), performance measurement techniques and key performance indicators (KPIs) used at the company. As the theme of green supply chain is evolving, the initial questions were designed to understand the perspective of the case-company over various issues related to supply chain performance measurement. Past literature in GSC, supplier selection and performance 
evaluation have been consulted to draft the questions in a manner that helps to explore the current performance evaluation technique in the company and to develop more appropriate technique for environmental performance measurement. Semi-structured interview based technique is used to collect relevant information related to GSC and performance measurement model from the managers and senior managers of the company. Initially, pilot study is conducted with researchers and practitioners to check whether the semi-structured questions are really providing the information related to the issues intended to explore in this study.

Transcription is used to improve the interviewing techniques, to detect the presence of leading questions on the part of the interviewer and to guard against selective memory (Flynn et al. 1990). Further, codification of transcripts helps to develop the pattern of the information emerged. The qualitative data is further analysed in 3 phases, Description, Analysis and Interpretation (Wolcott 1994). Alpha adopts a questionnaire-based technique to collect emission data from the supplier. These questionnaires are designed to ask the emission related questions from the suppliers. Appendix 1 presents the questionnaire used by Alpha.

\section{Analysis}

This research provides an opportunity to monitor the environmental performance measurement process of the FMCG Company 'Alpha'. The study analyses the supplier environmental performance evaluation model of 'Alpha' and attempts to understand why the performance evaluation framework is not implemented effectively. Multiple discussion with the managers at 'Alpha' site helps to understand the performance evaluation process and to identify potential challenges in successfully implementing it in the supply chain. In this section, the data collected during this research is analysed. Firstly, information related to 
suppliers' environmental performance evaluation system of 'Alpha' is presented; then, data collected is used to illustrate and substantiate the arguments and ideas raised in this research.

\section{The supplier environmental performance evaluation system to be implemented}

As a first step to set up the supplier environmental performance evaluation system, company Alpha had to select appropriate criteria for measuring the progress towards environmental objectives. An attempt was made to select indicators that apply to all stages in the supply chain.

Initially, the company started studying the applicability of more than 50 indicators from different sources in both the academic and practitioner the literature (Veleva et al., 2003; Hervani et al. 2005; Yakovleva, 2007) that were brought together. Particular emphasis was devoted to the indicators prescribed by the Supply Chain Operations Reference (SCOR) model, a process reference model endorsed by the Supply Chain Council (SCC) as the defacto standard supply chain management diagnostic tool (Poluha, 2007). Through a series of meetings and face-to-face interviews, involving managers from the Sustainability and Purchasing departments, correlations among selected indicators and their interdependencies have been highlighted. This has resulted in a simplified framework with the indicators reported in Table 1. Environmental indicators belong to five areas (Energy Use, GHG, Water, Waste, Renewable/Recycled Feedstock); furthermore suppliers are also required to provide general information about their annual output, annual volume supplier to Alpha and availability of Industry Certifications.

\section{$<<$ Insert table 1 here $>>$}

For data collection, Alpha sent an introductory letter to the suppliers to explain the objective of the process and ask their willingness to participate in it. 9 suppliers are selected with 
varied size and location for this program. In response to these environmental indicators, each supplier needed to select the specific reference unit from an appropriate drop down list and then provide the respective values. Therefore, the scorecard was circulated through the selected suppliers; data collected are then analysed, highlighting the emerging problems.

\section{One size does not fit for all}

One of the first findings from the observation of the implementation process of the suppliers environmental performance evaluation system at Alpha is that it is very difficult to collect the required information about suppliers' environmental performance by simply using the same set of indicators across different industries. Indeed, Alpha had designed a single set of indicators for all of their suppliers. However, It is unlikely that the same measures in one industry are suitable measures for other. For example, the usage of water and electricity consumption varies from industry to industry, as well as the way it is measured. Even the relative importance of measurement criteria can strongly differ from one industry to another. In addition, different reference units are employed in different industries. It was clearly visible from the data provided by the suppliers of Alpha, where suppliers responded the same question in different ways (Table 2). Despite the fact that the questionnaire had a provision to select the respective unit to represent data, most of the suppliers put their own unit values (Table 2). With reference to data received, it was found that each different industry has its own way of measuring different indicators (for instance, as regards energy consumption, Fragrances supplier used GJ/Tonne while Chemical products supplier used Total GJ). In such case, it becomes difficult to perform any comparative analysis. Therefore, the values presented in response to the scorecard prepared by Alpha are not of much sense.

After a thorough discussion with Company's global supply chain team, it was agreed that the questionnaire would not be sufficient enough to measure the environmental performance of 
suppliers. Designing and implementing the industry specific scorecard should be the way forward to understand the supplier in effective way and improve their performance.

\section{Lack of information about sub-tier suppliers}

It is found that the performance measurement scorecard is not able to collect any details about the supplier's supplier. In the global business environment where most firms outsourced their production, it is very important to know the process and environmental impacts of their outsourced partner. In order to achieve the overall objective of reducing environmental impact, it is important to understand and collect the information from sub tier suppliers too. Otherwise, the scorecard could just collect some useless information, as suppliers may be just outsourcing the more polluting bits of their production processes elsewhere.

One way of improving environmental performance is through instruments like supplier code of conduct. Alpha already had a supplier code of conduct but there are no details available regarding the any code of conduct for $2^{\text {nd }}$ tier suppliers. It is also crucial to understand, how Alpha's suppliers are measuring and monitoring the performance of their suppliers. If sub-tier suppliers are not participating to reduce the GHG emission and carbon footprint, there is no purpose of developing environmental performance scorecard for suppliers because it will simply act as a reporting tool.

\section{Difficulties in comparison of supplier performance}

There were, in total, 9 key suppliers identified to participate in the process. These suppliers are different in size, location and product supplied to Alpha. It is found that most of the suppliers who participated in this study were providing different raw materials or products to Alpha. Each of them has very different levels of energy usage, water consumption, GHG 
emissions and waste in response to the questionnaire. Due to this fact it is not wise to make any comparison between these suppliers in respect to their environmental performance. In the initial stage of developing scorecard, Alpha should encourage their suppliers to provide absolute values in response to the questionnaire. Company should also promote the scorecard not just as a performance measurement tool, but as a mechanism to mitigate risks, to adapt industry best practices which will not only helpful to the prime but every supplier in this programme by cutting cost and increasing profit margins. The scorecard could also be used a road towards industrial certifications like BSI and ISO. These benefits could be possible to achieve, if suppliers provide absolute values of GHG emissions, energy and water consumption, etc.

$<<$ Insert table 2 here $>>$

\section{Challenges to define Benchmark}

The biggest challenge was to make useful analysis of the data provided by supplier in response to the questionnaire. The key reasons behind this are:

- All suppliers were supplying different raw materials and products to the company. Therefore, they had a different level of resource consumption and waste creation depending on the specific processes in their particular industry.

- In absence of a benchmark, it was not possible to compare the performance of one over another. 
A possible way to provide benchmark for supplier performance is provided by the 'Ecoinvent' ${ }^{1}$ database. Such a database can be consulted to find the information about industry specific performance and use it as a benchmark to measure the supplier performance. All the details about energy, water, and GHG emission etc. are collected from the database. For example, the industry average for the plastic manufacturing industry is shown in Table 3 and this data could be applied as a benchmark to measure the performance of plastic bottle suppliers. The classification of suppliers in this study is based on the UK Standard Industrial Classification (SIC) index.

$$
<<\text { Insert table } 3 \text { here }>>
$$

\section{Enough Freedom, More Problems}

Another challenge was providing enough "freedom" to suppliers to reply the questionnaire. Alpha's intention was to provide flexibility to suppliers and encourage them to reply, but the suppliers perceived it in a different way and therefore there were no consistency in the responses (see Table 4).

$<<$ Insert table 4 here $>>$

1 Ecoinvent: is a non-profit entity, which was created in 1997. The ecoinvent Centre (originally called the Swiss Centre for Life Cycle Inventories) is a Competence Centre of the Swiss Federal Institute of Technology Zurich and Lausanne, the Paul Scherrer Institute (PSI), the Swiss Federal Laboratories for Materials Testing and Research (Empa), and the Swiss Federal Research station Agroscope Reckenholz-Tanikon (ART). It is the world's leading database with consistent and transparent, up-to-date Life Cycle Inventory (LCI) data. With more than 4000 LCI datasets in the areas of agriculture, energy supply, transport, biofuels and biomaterials, bulk and speciality chemicals, construction materials, packaging materials, basic and precious metals, metals processing, ICT and electronics as well as waste treatment. Source: Ecoinvent. (2007). Plastics Part II. Dubendorf: Swiss Centre of Lifecycle Inventories. 
Table 4 is a classic example of providing enough freedom where one of the participating suppliers did not select any specified measurement unit in the questionnaire. The supplier just added a comment "MWH". With these details, it was clear that the energy consumption was measured in $\mathrm{MWH}$, but there were no details available that this consumption represents the total consumption or the consumption for a tonne or a single unit of the product supplied to Alpha. At the end, Alpha has got many reference units that make the comparison more complicated. One of the managers at Alpha commented, "Our intention was to enable suppliers to provide us with the most accurate data. However, we understand that asking such unconstrained questions may give too much of freedom to the suppliers, and this information may not be useful to our purpose".

Therefore, the revised questionnaire should include a more "rigid" structure, with bandings (derived from industry averages) that can be associated with qualitative values ("very high", "high", "average", "low", etc.). Moreover, the multiple dimensions involved in the scorecard made data analysis process more difficult. During discussion with the company, it was found that all the dimensions have not the same priority in decision-making.

\section{Differences between Theory and Practice}

Evidence in support of the problems related to the practicality of the theoretical model was found in the case study. In literature review, various theoretical models are discussed to improve the environmental performance of supply chain. Although these models are argued as effective and efficient, limited discussion has been found about the challenges faced by the firm during the pre-implementation phase regarding data sharing, ethical issues etc. These challenges vary from firm to firm and also from industry to industry. In case of Alpha, the biggest challenge lies in the lack of consistency in the data; therefore, another round of data collection (which itself is a time consuming process) was needed. 


\section{Data validation}

During the analysis it was found that there was no data validation activity performed to ensure that the data provided by suppliers are authentic. There is a possibility that suppliers would have manipulated the requested data to hide their bad performance, to avoid being in the 'non-preferred' list of suppliers. Most often this is seen in case of smaller suppliers with limited resources. It is necessary to ensure that the data provided by suppliers is validated by data sharing and auditing protocols. Alpha should also communicate to suppliers that there will be no impact on the supplier status if they are not doing well during the initial phase. But, if corrective actions are not implemented, then their supplier status will be under investigation.

\section{Low familiarity with the performance evaluation models}

In the context of gathering information about the familiarity with performance evaluation models, it was found that the managers at the company have very limited information about them. This explains the issues faced by 'Alpha' in scorecard design and wrong expectations.

\section{Discussion}

Although a number of theoretical models are available in the literature for supplier environmental performance measurement, limited attempt has been made to understand these models from a real-world perspective. In this study, key issues identified in implementing the new model for environmental performance measurement are grouped in three categories, namely supply chain, culture and lack of innovation techniques issues. 
- Supply Chain Issues: Any exercise related to the environment performance evaluation in a company may not be well taken by the suppliers. Most of suppliers see this as a compliance exercise to find the culprits in terms of high emissions and downgrade supplier ratings. It is important to change this mindset by building a long term working relationship. Proper and effective support from the focal firm is desired to provide guidance to the suppliers for environmental performance improvement. Collaborative response from the buyer and supplier is required to tackle the environmental issues in the supply chain. Collaboration is the key to overcome the issues related to supply chain. Keeping every party on board and understanding their business environment can help to effectively implement performance measurement models. Building long-term relationship with suppliers helps to develop an effective green supply chain model. While developing a supply chain based performance measurement model, issues related to supply chain integration also need to be considered to align the agreed objectives. 
- Cultural Issues: When any firm decides to implement sustainability programme within the organisation, often a dedicated department is created. In such case, other departments presume that it is no longer their job to consider environmental concerns. This is the most common culture in many organisations. In current case study, Alpha created a department called "Sustainable sourcing development team" to provide guidelines and mechanism to achieve sustainability. Even though Alpha created a dedicated team, it should not confine the performance evaluation to this department and should promote the sustainability programme as a shared responsibility across the organisation. Literatures such as Fernandes et al. (2005) also suggest similar recommendations. Issues related to sustainability need to be considered as strategic importance for the organisation. A shared common ground must be created; when everyone in the organisation understands environmental performance concepts and drivers, they can also assist in improving the performance on sustainability.

- Lack of Innovation Techniques: Innovation helps to reduce the emission level, improve the product life cycle, and therefore promotes greener and healthier environment for future. Investing in $R \& D$ and sharing the knowledge with the suppliers along the supply chain is important to improve the environmental performance. Lack of clear idea about how to share knowledge and information related to the green technology is one of the key barriers to perform better on environmental criteria. Green technology needs to be developed to improve the process efficiency with less environmental impact. Focal firm/prime should play the role of 'big brother' to effectively transfer the technology to smaller suppliers and work together to minimise environmental impacts. 
In this study, it is found that effective communication, collaboration and commitment for improvement are the key factors to improve the SC environment performance. Four key stages are identified in this study to effectively implement the SC performance measurement process.

i. Supplier Selection: Supplier selection is a crucial phase to achieve sustainable supply chain. Often, these decisions are based on multiple selection criteria. Håkansson \& Wootz (1975) classified these criteria into supplier characteristics and bid characteristics. Supplier characteristics like reputation and size are the major factors, which influence the supplier selection decision. On the other hand, bid factors like price and quality offered by supplier also affect the supplier selection decision. Organisations should select the supplier selection method including the environmental and sustainable factors. Implementing the principles of green procurement at the early stage of supplier selection can significantly help to minimise environmental impacts in supply chains.

ii. Capability Evaluation: Only selecting the supplier with desired criteria is not enough for the SC performance improvement. In current competitive business environment, it becomes important to understand the capability of each supplier to participate in the environmental performance improvement process. The prime company can even offer support to suppliers in terms of providing trainings for non-compliance areas, giving access to necessary tools, offering technical support and expert advice, and integrating the learning process across the firm boundary. Understanding the capabilities of each party in the supply chain and aligning those capabilities to perform on environmental performance indicators are crucial in achieving the emission targets in supply chain. 
iii. Define/Modify KPIs: Based on the environmental objectives of the supply chain, performance indicators need to be defined, re-defined and modified. KPIs should be revised on regular intervals to incorporate recent and most updated environmental measures. KPIs should be carefully defined so that it really links with the environmental objectives of the supply chain.

iv. Performance measurement: Once the KPIs are defined, the most difficult job is the performance measurement. In absence of the proper benchmarking of environmental performance criteria, the environmental performance could be monitored by, (a) the benchmarking based on industry average, and (b) the benchmarking against nearest competitor. Industry average could be found using Ecoinvent database. Benchmarking against nearest competitors who has implemented the environmental score card is another way to measure your performance. Performance over KPIs should be monitored and analysed to find out particular areas of interests that need further improvement.

Improvements in the environmental performance of supply chains cannot be achieved by a single person or department. The organisation should understand the expectations of various stakeholders like employees, governments, NGO's, customers, investors and many community groups and suppliers. Engaging stakeholders at the early stage of supply chain sustainability programme will help to design and shape the programme and ensures the alignment of environmental objectives. Each organization must have a clear vision of sustainability in the supply chain. Furthermore, sustainability should not be seen as a separate dimension for performance evaluation. Indeed, some of the indicators identified by Alpha (Waste creation, Water and Energy use) may be an indicator of supplier efficient resource use; therefore, these indicators may be also interpreted about the ability of suppliers in 
implementing and using resource efficient manufacturing systems, that can have a direct impact on the financial dimension as well. Alpha, therefore, should incorporate environmental and sustainability dimensions in its standard supplier evaluation procedures.

Alpha has incorporated this vision to their sustainability plan and it reflects in its strategy, direction, objectives and commitment to improve the environmental performance of the SC. Even the company explains its commitment towards environment through their supplier code. But, simply having or designing supplier code or vision, firm cannot achieve sustainability unless it is not communicated to right people in the organisation. Therefore, communication becomes integral part of sustainability programme.

In order to develop a sustainable supply chain, the supplier's vision and code of conduct should be used as a base to set the correct expectations for suppliers and stakeholders. By sharing the code and vision, Alpha would be able to increase the awareness about their commitment towards sustainability. The Code of conduct should be made available at the beginning of a new supplier relationship. It will help to educate the potential suppliers on the importance of environmental issues. Even the code of conduct can be incorporated in the supplier contracts, and purchase orders. This will ensure the suppliers' commitment towards the environmental code of conduct. The focal firm can motivate the suppliers to improve their performance by providing incentives, support, and training. The incentive is not necessarily be monetary, rather it could also include:

i. Publicly recognition of supplier with awards like "Most Earth Friendly Supplier"

ii. Best-practice sharing across suppliers

iii. Increase business transactions

iv. Provide an opportunity to become Alpha's strategic partner

v. Sharing cost for environmental performance improvements

vi. Provide expertise to increase efficiency and capability of the supplier 
Alpha managers agreed on these incentives; indeed, the company started thinking about the possibility of having a sort of "league table" of Alpha's suppliers. Best-in-class suppliers could provide their best practices and share them with other firms (even belonging to different industries). A similar model has been recently implemented, with success, in the construction industry (see Skanska, 2012). It has to be recalled that, given the difficulty of finding cross-industry benchmarks, these systems should rather encourage year-by-year improvement of suppliers, regardless of its size and current sustainability programme, as already implemented by key players in the industry (P\&G, 2010).

Environment-friendly supply chains could not be designed by working only with first-tier suppliers. Collaborating with other sub-tiers suppliers should be encouraged in the supply chain. Working with suppliers will provide insight into the challenges at the supply chain level (not visible at organisational level). Despite the fact that several benefits could be achieved with collaboration, few risks can also be identified in terms of sharing information and skills outside the organisation. Improving the SC performance on carbon emission is a challenging task. The environmental performance measurement framework can be helpful in ranking the suppliers on their green performance and paves the way for designing green supply chain.

\section{Conclusion}

In a competitive market, consumers demand cheaper and higher quality products, on-time delivery and excellent after-sale services. Therefore, companies need to cut costs while maintaining a high level of quality and after-sale services. Various studies devoted to the analysis of customer-supplier relationships highlighted that attention should be paid on the management of the entire supply chain. In this context, supplier evaluation process plays a key role (Saen, 2007). In particular, suppliers' selection has assumed a strategic role in 
determining large customer firms' competitiveness, receiving an extensive attention in the literature (de Boer and van der Wegen, 2003). At the same time, in recent years, an increasing environmental awareness has favoured the incorporation of green and sustainability thinking in Supply Chain paradigms. Thus, green criteria have started to be considered also in the Supplier Selection and Evaluation Problem, (Sarkis, 2003). However, at present, most of the work on these topics has been aimed at identifying criteria, methods and models to solve the problem from a mathematical and theoretical point of view, with relatively little emphasis on researches that highlight and understand the challenges faced by organizations with the implementation of Green Supplier Selection and Evaluation models. In particular, the paper has presented a case study regarding the implementation process of a balanced scorecard approach for green supplier evaluation in a large multinational organisation operating in the fast-moving consumer goods industry, in order to understand the related real-life challenges. Indeed, applying a standard scorecard model may not be the appropriate choice for measuring environmental performance for a particular supply chain in which suppliers from several industries are involved. Uniqueness of each industry or each supply chain may not fit in the standard solution. Furthermore, including $2^{\text {nd }}$ tier suppliers performances in the evaluation may represent another hard task, along with validation of the data coming from suppliers.

Therefore, this study confirms that while the number of literature applications dealing with the greener supplier selection problem is growing, there is little empirical evidence of the transfer and usability of these applications into the real world. Indeed, as pointed out by Huang and Keska (2007), researchers in past have overly emphasized the need of quantitative methods and overlooked the importance of integration with business strategic thinking when it comes to supplier evaluation.

In present economic condition, the environmental performance measurement framework is important to improve the carbon-foot print of whole supply chain. Increasing imposition of 
carbon taxes and stringent green regulations in various countries across the globe make it necessary to evaluate the product and processes on the basis of green criteria. This study is relevant in this context and it paves the way for researches in designing effective tool for suppliers' evaluation in an attempt to develop green supply chain. The core value behind improving environmental performance of supply chain is to create, protect and generate longterm economic values for the stakeholders in the future. With sustainable supply chain, companies would be able to protect the long-term viability of its business and become pro active to face future business challenges.

Although the paper has highlighted the problems encountered while implementing the performance evaluation framework in a supply chain, the need for an efficient evaluation process in practice is still valid. Future research can focus more on developing a robust framework, which can mitigate the problems identified in this paper, and effectively evaluate the green performance of the supply chain. The paper can be further extended to address the shortcomings of this research. The sample size of the study is small which limits its findings to be generalised in other sectors. Future research could consider enlarging the sample of the empirical investigation to include other sectors, industries and geographical locations. Identified key-barriers to the implementation of supplier environmental performance measurement could be further investigated, also by asking key stakeholders in several industries to rate and rank these barriers in order to better understand their relative importance to different industrial and geographical contexts. Moreover, latest trends and directions within the literature connected to this research should also be continuously monitored and reviewed. Assessing the knowledge transfer rate of these researches in reallife applications and their capability of overcoming the cited barriers for the implementation of theoretical models in green supplier evaluation problem in practice. 


\section{References}

2degrees. (2011, Aug 11). Working Group Sustainable Supply Chain. Retrieved Aug 12, 2011, from http://www.2degreesnetwork.com: http://www.2degreesnetwork.com/working-groups/sustainable-supplychain/resources/supplier-environmental-sustainability-scorecards-pgs-story-so-far_2/

Awasthi, A., Chauhanb, S.S., Goyal, S. (2010). A fuzzy multicriteria approach for evaluating environmental performance of suppliers. International Journal of Production Economics, vol. 126(2), pp. 370-378.

Bai, C., Sarkis, J., (2010a) Green supplier development: Analytical evaluation using rough set theory, Journal of Cleaner Production, vol.18(12), pp. 1200-1210.

Bai, C., and Sarkis, J. (2010b). Integrating sustainability into supplier selection with grey system and rough set methodologies. International Journal of Production Economics, vol. $124(1)$, pp. 252-264.

Barnes, D. (2001) Research methods for the empirical investigation of the process of formation of operations strategy, International Journal of Operations \& Production Management, 21 (8), 1076 - 1095.

Benbasat, I., Goldstein, D.K., and Mead, M. (1987) The case research strategy in studies of information systems, Management Information systems Quarterly, 11 (3), 369-386.

Berg, B.L. (2004) Qualitative Research Methods for the Social Sciences. London: Allyn and Bacon.

Bhutta K.B, Huk F. (2002), Supplier selection problem: a comparison of the total cost of ownership and analytic hierarchy process approaches, Supply Chain Management: an International Journal, 7 (3), 126-135.

Bhutta M.K.S., (2003), Supplier selection problem: methodology literature review, Journal of International Technology and Information Management, 12 (2), 53-72.

Bruno, G., Esposito, E., Genovese, A., Passaro, R. (2012) AHP-based approaches for supplier evaluation: problems and perspectives. Accepted for publication in Journal of Purchasing and Supply Management.

Burgess, R.G. (1982) Field Research: A Sourcebook and Field Manual, Allen and Unwin, London.

Chan, F. T. S. and Kumar, N. (2007) Global supplier development considering risk factors using fuzzy extended AHP-based approach, Omega: The International Journal of Management Science, 35 (4), 417-431.

Chan, F.T.S., Kumar, N., Tiwari, M. K., Lau, H.C.W. Lau and Choy, K.L. (2008) Global Supplier Selection: A Fuzzy-AHP Approach, International Journal of Production Research 46(14), 3825 - 3857.

Choy, K.L., Lee, W.B., Lo, V. (2002) Development of a case based intelligent customersupplier relationship management system, Expert Systems with Applications 23 (3), 281-297.

de Boer, L., Labro, E., \& Morlacchi, P. (2001). A review of methods supporting supplier selection, European Journal of Purchasing \& Supply Management, 75-89.

de Boer L., van der Wegen L.L.M. (2003), Practice and promise of formal supplier selection: a study of four empirical cases. Journal of Purchasing \& Supply Management, 9 (3), pp.109-118.

Dekker, H. C. (2003). Value Chain Analysis in interfirm relationships: a field study. Management Accounting Research, 1-23.

Dickson, G.W., 1966. An analysis of vender selection systems and decisions. Journal of Purchasing 2 (1), 5-17.

do Paço, A., Raposo, M. (2009). "“Green" segmentation: an application to the Portuguese consumer market", Marketing Intelligence \& Planning, Vol. 27, 3, pp.364 - 379 
Ecoinvent. (2007). Plastics Part II. Dubendorf: Swiss Centre of Lifecycle Inventories.

Eisenhardt, K.M. (1989) Building theory from case study research, Academy of Management Journal, 14 (4), 532-550.

Fernandes, K., Raja, V., \& Whalley, A. (2006). Lessons from implementing the balanced scorecard in a small and medium size manufacturing organization. Technovation 26, 623-634.

Florez-Lopez, R., 2007. Strategic supplier selection in the added-value perspective: A CI approach. Information Sciences 177 (5), 1169-1179.

Flynn, B.B., Sakakibara, S., Schroeder, R.G., Bates, K.A. and Flynn, E.J. (1990) Empirical research in operations management, Journal of Operations Management, 9 (2), 250284.

Forker, L.B., Mendez, D., 2001. An analytical method for benchmarking best peer suppliers. International Journal of Operations and Production Management 21 (1-2), 195-209.

Genovese, A., Koh, S.C.L., Bruno, G., Esposito, E. (2013). Greener Supplier Selection: Stateof-the-Art and Some Empirical Evidence. International Journal of Production Research, in press.

Gunasekaran, A., Patel, C., \& McGaughey, R. (2004). A framework for supply chain performance measurement. International Journal of Production Economics Vol 84, 333-347.

Gunasekaran, A., Irani, Z. (2010). Modelling and analysis of outsourcing decisions in global supply chains. International Journal of Production Research, Vol. 48(2), pp. 301-314.

Håkansson, H., \& Wootz, B. (1975). Supplier Selection in an International Environment: An Experimental Study. Journal of Marketing Research, Vol. 12, No. 1, 46-51.

Handfield, R., Steven, R., Srouft, R., \& Melnyk, S. A. (2002). Applying environmental criteria to supplier assessment: A study in the application of the analytical hierarchy process. European Journal of Operational Research, vol. 141, pp. 70-87.

Harland, C. (1996). Supply chain management: relationships, chain and networks. British Journal of Management Vol 7 (special issue), 63-80 .

Hervani, A., Helms, M. \& Sarkis, J., 2005. Performance measurement for green supply chain management. Benchmarking: An International Journal, 12 (4), 53-330.

Ho, W., Xu, X. and Dey, P.K. (2009). Multi-criteria decision making approaches for supplier evaluation and selection: a literature review. European Journal of Operational Research, vol. 202, pp. 16-24.

Hong, G.H., Park, S.C., Jang, D.S., Rho, H.M., 2005. An effective supplier selection method for constructing a competitive supply-relationship. Expert Systems with Applications 28 (4), 629-639.

Hsu, C., Hu A., (2009). Applying hazardous substance management to supplier selection using analytic network process. Journal of Cleaner Production, vol. 17(2), pp. 255264.

Huang, S.H., Keska, H., 2007. Comprehensive and configurable metrics for supplier selection. International Journal of Production Economics 105 (2), 510-523.

Humphreys, P.K., McCloskey, A., McIvor, R. Maguire, L., Glackin, C. (2006). Employing dynamic fuzzy membership functions to assess environmental performance in the supplier selection process. International Journal of Production Research, vol. 44, pp. 2379-2419.

Kannan, G., Haq, A. N., Sasikumar P., Arunachalam, S., (2008). Analysis and selection of green suppliers using interpretative structural modelling and analytic hierarchy process. International Journal of Management and Decision Making, vol. 9(2), pp. 163 - 182. 
Jain, V., Wadhwa, S. and Deshmukh, S. G.(2007) Supplier selection using fuzzy association rules mining approach, International Journal of Production Research, vol. 45(6), pp. 1323-1353.

Lamming, R., Cousins, P.D., \& Notman, D.M. (1996). Beyond supplier evaluation. Relationship evaluation programmes. European Journal of Purchasing and Supply Management, vol. 2(4), pp. 173-181.

Lee, H., \& Billington, C. (1992). Managing supply chain inventory: Pitfalls and opportunities. Sloan Management Review Vol 33, 65-73.

Liu, J., Ding, F.Y., Lall, V., 2000. Using data envelopment analysis to compare suppliers for supplier selection and performance improvement. Supply Chain Management: An International Journal 5 (3), 143-150.

Lu, L. Y.Y., Wu, C.H. and Kuo, T.-C. (2007) Environmental principles applicable to green supplier evaluation by using multi-objective decision analysis. International Journal of Production Research, vol. 45(18), pp. 4317-4331.

Lyons, A.C., Mondragon, C.A.E., Bremang, A., Kehoe, D.F., Coleman, J. (2005). Prototyping an information system's requirements architecture for customer- driven supply-chain operations. International Journal of Production Research, vol. 43(20), 4289-4319.

Meredith, J. R., Raturi, A., Amoako-Gyampah, K. and Kaplan, B. (1989) Alternative research paradigms in operations, Journal of Operations Management, 8 (4), 297-326.

$\mathrm{Ng}$, W.L., 2008. An efficient and simple model for multiple criteria supplier selection problem. European Journal of Operational Research 186 (3), 1059-1067.

Noci, G. (1997). Designing green vendor rating systems for the assessment of a supplier's environmental performance. European Journal of Purchasing and supplier's environmental performance, 103-114.

O'Neal, C. (2006). Concurrent engineering with early supplier involvement: a crossfunctional challenge. Journal of Supply Chain Management, vol. 29(2), pp. 2-9., March).

P\&G. (2010). P\&G launches supplier environmental sustainability scorecard. Retrieved August, 10, 2011, from: http://news.pg.com/press-release/pg-corporateannouncements/pg-launches-supplier-environmental-sustainability-scorecard.

Poluha, R.G. (2007) Application of the SCOR Model in Supply Chain Management. Cambria Press, Youngstown.

Ramanathan R., (2007), Supplier selection problem: integrating DEA with the approaches of total cost of ownership and AHP, Supply Chain Management: an International Journal, $12(4), 258-261$.

Saaty, T.L. (1980). The Analytic Hierarchy Process. McGraw Hill International, New York.

Saaty, T.L. (1994). Fundamentals of Decision Making and Priority Theory with the Analytic Hierarchy Process. RWS Publications, Pittsburg, PA.

Saaty, T.L. (2001). The Analytic Network Process: Decision Making with Dependence and Feedback, RWS Publications, Houston.

Saen R.F., (2007), A new mathematical approach for suppliers selection: Accounting for nonhomogeneity is important, Applied Mathematics and Computation, vol.185, pp. 84-95.

Sarkis, J. (2003). A strategic decision framework for green supply chain management. Journal of Cleaner Production, vol. 11(4), pp. 397-409.

Sasikumar, P. Noorul Haq, A. (2010). Integration of closed loop distribution supply chain network and 3PRLP selection for the case of battery recycling. International Journal of Production Research, vol. 49(11), pp. 3363-3385. 
Seuring, S., Müller, M. (2008). From a literature review to a conceptual framework for sustainable supply chain management. Journal of Cleaner Production, vol.16(15), $1699-1710$.

Skanska (2012). Supply Chain Sustainability School. Available online at: http://www.supplychainschool.co.uk/about/about-our-partners/skanska.aspx

Sonmez, M. (2006). A review and critique of supplier selection process and practices. Occasional Paper, 2006:1. Loughborough: Business School, Loughborough.

Tsai, W.H., Hung, S.J. (2009). A fuzzy goal programming approach for green supply chain optimisation under activity-based costing and performance evaluation with a valuechain structure. International Journal of Production Research, vol. 47(18), pp. 49915017.

Vachon, S., Klassen, R. (2006). Green project partnership in the supply chain: the case of the package printing industry. Journal of Cleanear Production, vol. 14, pp. 661-671.

Vachon, S., Klassen R.D. (2008). Environmental management and manufacturing performance: the role of collaboration in the supply chain. International Journal of Production Economics, vol. 111, pp. 299-315.

Veleva, V., Hart, M., Greiner, T. and C. Crumbley. "Indicators for measuring environmental sustainability: A case study of the pharmaceutical industry, Benchmarking: An International Journal, (10:2), 2003, pp. 107-119.

Yakovleva, N. (2007). Measuring the sustainability of the food supply chain: a case study of the UK, Journal of Environmental Policy and Planning, (9:1), pp. 75-100.

Weber C.A. Current J.R., Benton W.C., (1991), Vendor selection criteria and methods, European Journal of Operational Research, n.50, 2-18.

Wolcott, H. F. (1994). Transforming Qualitative Data. London: SAGE Publications Inc.

Yin, R.K. (2003) Case Study Research: Design and Methods, Sage Publications, London.

Zhu, Q., \& Sarkis, J. (2004). Relationships between operational practices and performance among early adopters of green supply chain management practices in Chinese manufacturing enterprises. Journal of Operations Management Vol 22, 265-289.

Zhu, Q., Dou, Y. Sarkis, J. (2010). A portfolio-based analysis for green supplier management using the analytical network process. Supply Chain Management: An International Journal, vol. 15(4), pp.306- 319. 


\section{Appendix:}

Appendix 1: Company Alpha's questionnaire to collect information from suppliers

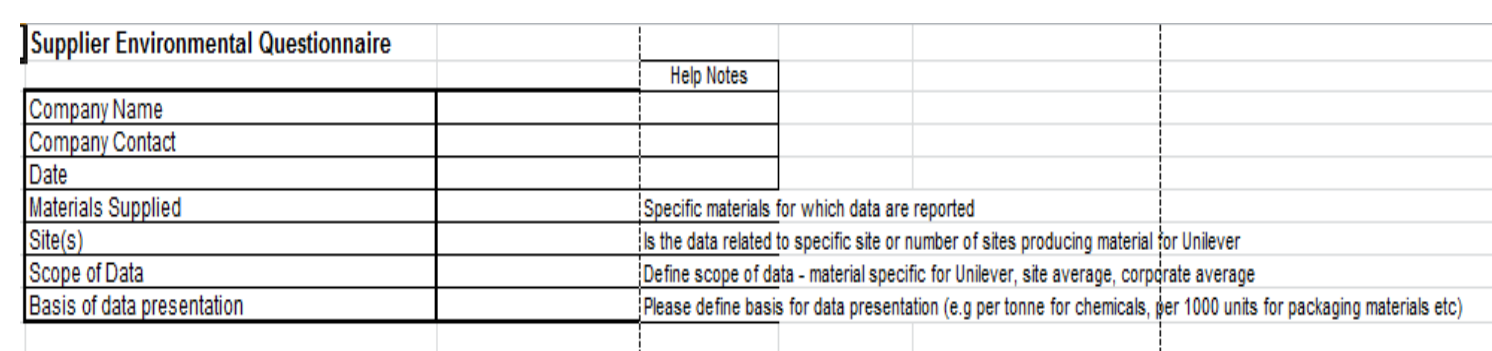

\begin{tabular}{|c|c|c|c|c|c|}
\hline & |Unit (select from menu)| & 2010 Data & 2009 Data & Comments & Help Notes \\
\hline \multicolumn{6}{|l|}{ Energy Use } \\
\hline Electricity (from Grid) & GJTonne & & & & Electricity purchased directly from National grid \\
\hline Electricity (own generation) & GJTonne & & & & Electricity generated either on site or from other industrial source (not national grid) \\
\hline Fuel Use on site & Choose from list & & & & Fuel used on site for heat, steam etc generation \\
\hline Other energy use (purchased heat, steam) & & & & & Detal other energy sources - brought in energy from off-site (heat, steam) \\
\hline \multicolumn{6}{|l|}{ GHG } \\
\hline $\begin{array}{l}\text { GHG emissions from Energy Usage } \\
\text { CO2 emissions from other sources (ea processin }\end{array}$ & KogTonne & & & & 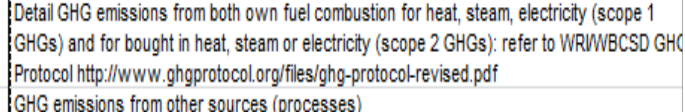 \\
\hline \multicolumn{6}{|r|}{ 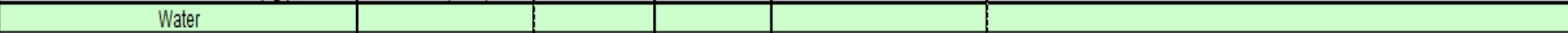 } \\
\hline Water consumption (all sources) & Cubic metre/Tonne & & & & Water input into site(s) from all sources - mains supply, borehole etc \\
\hline Water discharge & Cubic metre/Tonne & & & & Total water discharge from site \\
\hline Total COD & Kg/000 units & & & & Detail of pollution discharge from site \\
\hline Are site(s) in water stressed areas & Name of sites & & & & I dentify which ste(s) are in water stressed areas using the 'Global Water Tool' \\
\hline \multicolumn{6}{|l|}{$\begin{array}{c}\text { Waste } \\
\end{array}$} \\
\hline Hazardous waste & Choose from list & & & & Detail hazardous waste materials which are disposed. \\
\hline Non-hazardous waste & Ko, 000 units & & & & Detail non - hazardous waste materials which are disposed. \\
\hline \multicolumn{6}{|l|}{ RenewablelRecycled Feedstock } \\
\hline Renewable Material as Feedstock & Choose from list & & & & $\begin{array}{l}\text { Please detail the amount of raw materials which have been directly sourced from a renewab } \\
\text { feedstock (e.g. plant oils, corn etc) }\end{array}$ \\
\hline Recycled Material as Feedstock & Choose from list & & & & 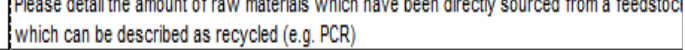 \\
\hline \multicolumn{6}{|l|}{\begin{tabular}{|c|} 
General \\
\end{tabular}} \\
\hline Annual Output & Tonne & & & & This must be completed if information is provided on a Total Emissions' basis \\
\hline Annual Unilever volume & Tonne & & & & \\
\hline Industry Certification/ Environmental Programmes & A Choose from list & & & & Please detail any industry certification that you have eg IS0140001; Responsible care; IRIMA \\
\hline Data Protocol used & Description & & & & Please describe the protocol used as basis for data collection - e.g. WRWWBCSD GHG Protoc \\
\hline
\end{tabular}


Production Planning and Control: The Management of Operations 2014; 25 (13-14): 1198 - 1211.

\section{Appendix 2: Interview Questionnaire}

1) What is supplier selection process at 'Alpha'?

2) Are any social and environmental factors incorporated with the existing supplier selection process of Alpha?

3) How did Alpha measure the performance of its supply chain?

4) What are the problems and challenges with the existing performance measurement process?

5) To what extent are you aware of Alpha's Supplier code of conduct?

6) What do you know about the Balanced Scorecard approach? 
Production Planning and Control: The Management of Operations 2014; 25 (13-14): 1198 - 1211.

Table 1: Environmental indicators for supplier performance evaluation

\begin{tabular}{|l|l|}
\hline \multirow{5}{*}{ Energy Use } & Electricity (from grid) \\
\cline { 2 - 2 } & Electricity (own generation) \\
\cline { 2 - 2 } & Fuel use on site \\
\cline { 2 - 2 } & Other energy use (purchased heat, steam) \\
\hline WHG & GHG emissions from Energy Usage \\
\cline { 2 - 2 } & $\mathrm{CO}_{2}$ emissions from other sources \\
\hline \multirow{5}{*}{ Waste } & Water consumption (all sources) \\
\cline { 2 - 2 } & Water discharge \\
\cline { 2 - 2 } & Total Chemical Oxygen Demand (COD) \\
\cline { 2 - 2 } & Number of sites in water stressed areas \\
\hline Renewable/Recycled Feedstock & Renewable Material as Feedstock \\
\cline { 2 - 2 } & Recycled Material as Feedstock \\
\cline { 2 - 2 } & Non-hazardous waste production \\
\hline General & Annual Output \\
\cline { 2 - 2 } & Annual Volume supplied to Alpha \\
\cline { 2 - 2 } & Industry Certification/Environmental Programmes \\
\hline
\end{tabular}


Table 2: Energy usage and GHG emission measurement of suppliers across industries.

\begin{tabular}{|c|c|c|c|c|c|c|c|c|c|}
\hline Suppliers & 1 & 2 & 3 & 4 & 5 & 6 & 7 & 8 & 9 \\
\hline Industry & Fragrance & Plastic Bottles & $\begin{array}{l}\text { Dispensing } \\
\text { systems }\end{array}$ & $\begin{array}{l}\text { Antiperspirant } \\
\text { Actives }\end{array}$ & $\begin{array}{l}\text { Sodium } \\
\text { Carbonate }\end{array}$ & Soda Ash & $\begin{array}{l}\text { Linear Alkyl } \\
\text { Benzene }\end{array}$ & \multicolumn{2}{|c|}{$\begin{array}{c}\text { Aluminium Aerosol } \\
\text { Cans }\end{array}$} \\
\hline $\begin{array}{l}\text { Total Energy } \\
\text { Usage }\end{array}$ & 1.04 & 9.1 & 725 & 1848.78 & 19.71 & 80.6 & 68991 & 1761015 & 5.584 \\
\hline $\begin{array}{l}\text { Basis of data } \\
\text { presentation }\end{array}$ & $\begin{array}{l}\text { per } \\
\text { Tonne }\end{array}$ & $\begin{array}{c}\text { Per ton of } \\
\text { packaging } \\
\text { material }\end{array}$ & $\begin{array}{l}\text { Aggregated } \\
\text { site data }\end{array}$ & $\begin{array}{c}\text { Total usage per } \\
\text { year }\end{array}$ & - & per unit & - & $\begin{array}{c}2010 \\
\text { Off take }\end{array}$ & $\begin{array}{l}1000 \\
\text { units }\end{array}$ \\
\hline $\begin{array}{l}\text { Measurement } \\
\text { Unit }\end{array}$ & \multicolumn{2}{|c|}{ GJ/Tonne GJ/Tonne } & $\begin{array}{l}\text { Total GJ } \\
(000 \text { 's })\end{array}$ & Total GJ (000's) & $\begin{array}{l}\text { Total GJ (000's) } \\
\text { and } \mathrm{mWh}\end{array}$ & $\begin{array}{l}\text { Total GJ } \\
(000 \text { 's })\end{array}$ & $\begin{array}{l}\text { Total GJ } \\
(000 \text { 's })\end{array}$ & $\mathrm{mWh}$ & $\begin{array}{c}\text { Total GJ } \\
(000 \text { 's })\end{array}$ \\
\hline GHG Emission & 445 & 710 & 1147 & 3.031 & 68434.6 & 122.75 & 80.6 & 3142621 & 32.17 \\
\hline $\begin{array}{l}\text { Measurement } \\
\text { Unit }\end{array}$ & $\mathrm{Kg}$ /Tonne & $\begin{array}{l}\mathrm{Kg} / \\
\text { Tonne }\end{array}$ & Total Tonnes & Total Tonnes & $\mathrm{Kg}$ /Tonne & $\begin{array}{l}\text { Total } \\
\text { Tonnes }\end{array}$ & Total Tonnes & $\begin{array}{c}\text { Total } \\
\text { Tonnes }\end{array}$ & $\begin{array}{l}\mathrm{Kg} / \\
000 \text { 's } \\
\text { units }\end{array}$ \\
\hline
\end{tabular}


Production Planning and Control: The Management of Operations 2014; 25 (13-14): 1198 - 1211.

Table 3: Input and output data for Plastic Bottle manufacturing (Source: Ecoinvent, 2007)

\begin{tabular}{|l|c|c|}
\hline INPUTS & & per kg PTA \\
\hline Materials & & \\
\hline p-xylene & $\mathrm{g}$ & 661.45 \\
\hline acetic acid & $\mathrm{g}$ & 49.96 \\
\hline sodium hydroxide & $\mathrm{g}$ & 1.45 \\
\hline compressed air & $\mathrm{m} 3$ & 0.37 \\
\hline nitrogen & $\mathrm{g}$ & 48.83 \\
\hline Energy & & \\
\hline thermal fuels & $\mathrm{MJ}$ & 1.63 \\
\hline electricity & $\mathrm{MJ}$ & 1.63 \\
\hline steam & $\mathrm{g}$ & 640 \\
\hline Water & & \\
\hline demineralised water & $\mathrm{g}$ & 424.73 \\
\hline cooling water & $\mathrm{g}$ & 347.71 \\
\hline
\end{tabular}

\begin{tabular}{|l|c|c|}
\hline OUTPUTS & & per kg PTA \\
\hline PTA & $\mathrm{g}$ & 1000 \\
\hline Emission to air & & \\
dust & $\mathrm{mg}$ & 90 \\
\hline aromatic hydrocarbons & $\mathrm{mg}$ & 378 \\
\hline other hydrocarbons & $\mathrm{mg}$ & 9 \\
organics & $\mathrm{mg}$ & 101 \\
Emission to water & & \\
BOD & $\mathrm{mg}$ & 1301 \\
suspended solids & $\mathrm{mg}$ & 256 \\
dissolved organics & $\mathrm{mg}$ & 13 \\
hydrocarbons & $\mathrm{mg}$ & 1 \\
Waste & & \\
hazardous waste & $\mathrm{g}$ & 0.2 \\
inert chemicals & $\mathrm{g}$ & 6 \\
\hline
\end{tabular}


Production Planning and Control: The Management of Operations 2014; 25 (13-14): 1198 - 1211.

Table 4: An example of inconsistency in data units

\begin{tabular}{|c|c|c|c|c|}
\hline & Unit (select from menu) & 2010 Data & 2009 Data & Comments \\
\hline \multicolumn{5}{|l|}{ Energy Use } \\
\hline Electricity (from Grid) & Choose from list & 6,446 & & MWH \\
\hline Electricity (own generation) & Choose from list & $\mathrm{n} / \mathrm{a}$ & & \\
\hline Fuel Use on site & Choose from list & $\mathrm{n} / \mathrm{a}$ & & \\
\hline Other energy use (purchased heat, steam) & Choose from list & $1,754,569$ & & m3 Gass \\
\hline \multicolumn{5}{|l|}{ GHG } \\
\hline GHG emissions from Energy Usage & Choose from list & 3,142,621 & & $\mathrm{Kg}$ \\
\hline CO2 emissions from other sources (eg processing) & Choose from list & $\mathrm{n} / \mathrm{a}$ & & Not reported separately \\
\hline \multicolumn{5}{|l|}{ Water } \\
\hline Water consumption (all sources) & Choose from list & 15,792 & & m3 \\
\hline Water discharge & Choose from list & 15,792 & & m3 \\
\hline Total COD & Choose from list & & & \\
\hline Are site(s) in water stressed areas & Name of sites & & & \\
\hline \multicolumn{5}{|l|}{ Waste } \\
\hline Hazardous waste & Choose from list & 43,982 & & $\mathrm{Kg}$ \\
\hline Non-hazardous waste & Choose from list & 27,269 & & $\mathrm{Kg}$ \\
\hline
\end{tabular}

